\title{
Cardiac Lead Erosion
}

National Cancer Institute

\section{Source}

National Cancer Institute. Cardiac Lead Erosion. NCI Thesaurus. Code C99931.

A cardiac lead has damaged local tissue enough to require treatment. (ACC) 